\title{
RGS 2 expression is regulated by TSH and inhibits TSH receptor signaling
}

\author{
Markus Eszlinger, Hans-Peter Holzapfel, Carsten Voigt, Cord Arkenau and Ralf Paschke \\ III Medical Department, University of Leipzig, Ph.-Rosenthal-Str. 27, D-04103 Leipzig, Germany \\ (Correspondence should be addressed to R Paschke; Email: pasr@medizin.uni-leipzig.de)
}

\begin{abstract}
Objective: A new family of guanosine triphosphatase-activating proteins known as regulators of $\mathrm{G}$ protein signaling (RGS) has been found to regulate the desensitization of several G protein-coupled ligandinduced processes. The expression of nine RGS mRNAs was found in human thyroid tissue (RGS 2, 3, $5,6,9,10,12,14$ and 16). At present, little is known as to whether any of the RGS proteins play a role in TSH signaling.

Design and methods: To explore the involvement of RGS proteins in the regulation of TSH receptor (TSHR) signal transduction, mRNA expression levels of the RGS proteins were analyzed after TSH stimulation of human thyroid primary cultures by real-time RT-PCR. Furthermore, the effects of RGS 2 expression on TSHR signaling (cAMP-, inositol-3-phosphate accumulation, TSHR cell surface expression) were studied in COS-7 cells.

Results: Only RGS 2 mRNA was found to be regulated by TSH in thyroid primary cultures. Co-expression of RGS 2 and TSHR in COS-7 cells reduced the TSHR signaling via inositol-3-phosphate but not via cAMP after stimulation with TSH.

Conclusion: TSH-dependent RGS 2 mRNA expression and the suppression of $\mathrm{TSH}_{-} \mathrm{G}_{\mathrm{q}} \alpha$ signaling by the overexpression of RGS 2 imply that RGS 2 is involved in TSHR-induced $\mathrm{G}_{\mathrm{q}}$ signal transduction.
\end{abstract}

European Journal of Endocrinology 151 383-390

\section{Introduction}

Recently, a new class of guanosine triphosphatase-activating proteins (GAP) has been identified and called regulators of $\mathrm{G}$ protein signaling (RGS) (1-6). Their role in the regulation of the signal transduction of $G$ protein-coupled receptors and their involvement in pathogenetic mechanisms has been demonstrated for several diseases $(2-4,7-12)$. The family of RGS proteins has been classified into six subgroups, with more than 20 known mammalian members to date (13). RGS proteins have been shown to interact specifically with distinct $\mathrm{G}$ protein $\alpha$ subunits and their corresponding receptors. They exhibit a cell-specific and developmentally dependent expression and are found in a broad range of tissues $(7,14-21)$. While RGSPX1 has been shown to interact with the G protein $\alpha$ subunit $\mathrm{s}$, the other RGS proteins interact directly with the $\mathrm{G}$ protein $\alpha$ subunits $\mathrm{i}, \mathrm{q}, \mathrm{o}, 11,12,13, \mathrm{t}$ and $\mathrm{z}(1-3,6,22-27)$.

Thyrotropin (TSH) signaling uses a variety of G proteins $(28,29)$. The main signal transduction pathways are mediated by coupling to $\mathrm{G}_{\mathrm{s}} \alpha$ or $\mathrm{G}_{\mathrm{i}} \alpha$ with activation of adenylyl cyclases and increased production of cAMP and the activation of phospholipase C (PLC) by coupling to $G_{q / 11}(28)$. The relevance of other TSH receptor (TSHR) - G protein interactions such as $G_{s}, G_{i}$ and $G_{q}$ has not been investigated in vivo $(28,29)$. Moreover, there are few data about the detailed signal transduction of the TSHR and its regulation at the $G$ protein level. While a role for RGS proteins in the specific regulation of signal transduction of other $\mathrm{G}$ protein-coupled receptors like the parathyroid hormone (PTH) receptor, the $G$ protein-coupled chemoattractant receptors and other receptors $(8,9,11,12,17,30-32)$ has been established, the relevance of the RGS proteins in the human thyroid and their influence on TSHR signaling are largely unknown. In a recent study (A Tönjes, S Miedlich, H-P Holzapfel, M Eszlinger \& R Paschke, unpublished observations), we were able to detect mRNAs of nine of the RGS family members (RGS 2, 3, 5, 6, 9, 10, 12, 14 and 16) in the human thyroid. Moreover, six out of these nine RGS transcripts (RGS 2, 6, 9, 10, 12 and 16) are characterized by a differential expression between hot or cold thyroid nodules (CTN) and their corresponding normal surrounding tissue.

The goal of these experiments was therefore to identify a possible regulation of these differentially expressed RGS mRNAs by TSH and to investigate their involvement in downstream TSHR signaling. 


\section{Materials and methods}

\section{Samples}

Specimens of non-nodular thyroid tissues of consecutive patients undergoing thyroid resection for treatment of their CTNs were obtained at surgery. All patients with a CTN were euthyroid with normal TSH levels and negative thyroid antibodies.

The study was approved by the local ethics committee. Informed consent was obtained from all patients before surgery.

\section{Primary thyroid cell culture}

Fresh non-nodular thyroid tissue was removed in phosphate-buffered saline (PBS) buffer ( $\mathrm{pH} 7.4)$ and cut into small pieces. The buffer was decanted and the tissue was incubated in $15 \mathrm{ml}$ PBS-dispase II solution ( $\mathrm{pH}$ 7.4; dispase II $0.48 \mathrm{~g} / 100 \mathrm{ml} \mathrm{PBS})$ for $15 \mathrm{~min}\left(37^{\circ} \mathrm{C}\right)$ during continuous stirring. Afterwards, the cell suspension was filtered and the tissue pieces were again incubated with $15 \mathrm{ml}$ fresh PBS-dispase II solution for a further $15 \mathrm{~min}\left(37^{\circ} \mathrm{C}\right)$. The supernatant (cell suspension) was centrifuged $(2 \mathrm{~min} / 200 \boldsymbol{g})$ and the pellet carefully resuspended in 1-2 ml RPMI medium ( $\mathrm{pH} 7.4$; $10 \%$ fetal calf serum and $1 \%$ antibiotics, penicillin and streptomycin) and put on ice. After several rounds of dispase treatment, the resuspended cells were pooled in $15 \mathrm{ml}$ Falcon tubes, centrifuged $(2 \mathrm{~min} / 200 \boldsymbol{g})$ and the pellet was resuspended in a small volume of RPMI medium (there were approximately $5 \times 10^{6}$ cells $/ 40 \mu \mathrm{l}$ pellet) and divided into six-well plates. After 3 to 5 days of incubation without changing the culture media the primary thyroid cell culture was ready for further experiments. Five days after splitting the cells, TSH $(1 \mathrm{mU} / \mathrm{ml})$ was added to the medium and the cells were further incubated for different times ( 1 to $48 \mathrm{~h}$ ). After incubation, the medium was removed and the cells were placed directly on ice, scraped and stored in liquid nitrogen for RNA extraction and RT-PCR experiments.

\section{RNA preparation and cDNA synthesis}

RNA was prepared with an Atlas pure RNA isolation kit according to the manufacturer's instructions (Clontech, Palo Alto, CA, USA). The quality of the RNA samples was assessed by electrophoresis through denaturating agarose gels and staining with ethidium bromide. $18 \mathrm{~S}$ and $28 \mathrm{~S}$ RNA bands were visualized under u.v. illumination. The extraction yield was quantified spectrophotometrically.

Total RNA $(1 \mu \mathrm{g})$ was used for cDNA synthesis. Briefly, for first strand synthesis oligo-dT primers were added to each sample ( $2 \mu \mathrm{mol}$ final concentration) and heated to $70^{\circ} \mathrm{C}$ for $2 \mathrm{~min}$. The samples were placed on ice and a $7.5 \mu \mathrm{l}$ master mix containing $1 \mu \mathrm{l}$ reverse transcriptase (MMLV; GibcoBRL, Karlsruhe,
Germany), $4 \mu \mathrm{l}$ RT buffer, $1 \mu \mathrm{l}$ dNTPs (GibcoBRL), $0.5 \mu \mathrm{l}$ RNAse inhibitor (Peqlab, Erlangen, Germany) and $1 \mu$ l dithiothreitol (GibcoBRL) was added to each sample followed by an incubation at $42{ }^{\circ} \mathrm{C}$ for $1 \mathrm{~h}$. Finally, the product was denaturated for $5 \mathrm{~min}\left(94^{\circ} \mathrm{C}\right)$ and $80 \mu \mathrm{l}$ RNAse-free water was added.

\section{Real-time RT-PCR}

The quantification of the RGS mRNA by real-time PCR was performed using a LightCycler (Roche, Mannheim, Germany). Oligonucleotide primers were designed to be intron spanning and were tested with RT-probes. The primers were purchased from MWG Biotech AG (Ebersberg, Germany). LightCycler hybridization probes were designed and supplied by $O$ Landt, TIB MOLBIOL (Berlin, Germany). Sequences were obtained from the GenBank database. Primers, probes and RT-PCR conditions are summarized in Table 1. First, an optimal PCR for all investigated genes was established using the LightCycler-DNA Master SYBR Green I Kit (Roche) as previously described (33). PCRs were processed through 40 cycles of a three-step PCR, including $0 \mathrm{~s}$ of denaturation at $95^{\circ} \mathrm{C}$, a $7 \mathrm{~s}$ template-dependent annealing phase and a template-dependent elongation at $72{ }^{\circ} \mathrm{C}$ ranging from 7 to $11 \mathrm{~s}$ for the different PCR amplicons. Afterwards, the amplicons were checked by agarose gel electrophoresis for a single band of the expected size. The PCR products were cloned in the pGEM-T vector (Promega, Madison, WI, USA) and were subsequently sequenced. The quantification of the different targets was performed using the LightCycler-DNA Master Hybridization Probes Kit (Roche). A $20 \mu \mathrm{l}$ reaction consisted of $2 \mu \mathrm{l}$ LightCycler-DNA Master Hybridization Probes (containing Taq DNA polymerase, reaction buffer, dNTP mix (with dUTP instead of dTTP) and $10 \mathrm{mM} \mathrm{MgCl}_{2}$ ), additional $\mathrm{MgCl}_{2}$ according to the optimization, $0.5 \mu \mathrm{M}$ of each primer, $0.15 \mu \mathrm{M}$ of each hybridization probe (3'-fluorescein labeled and 5'-LightCycler Red 640 labeled) and $2 \mu \mathrm{l}$ template. Dilutions of the plasmids were used to generate calibration curves for each template. The quantification of each template was performed in duplicate in one PCR run. Because TSH treatment did not influence the expression values of the housekeeping gene $\beta$-actin $(P=0.9)$, the determined RGS ratios were normalized to the ratio of this housekeeping gene to normalize for differences in the amount of cDNA added to the reactions.

\section{Cell culture and transfection}

COS-7 cells were grown in Dulbecco's modified Eagle's medium (DMEM) supplemented with 10\% fetal bovine serum, 100 units $/ \mathrm{ml}$ penicillin and $100 \mu \mathrm{g} / \mathrm{ml}$ streptomycin (GibcoBRL) at $37^{\circ} \mathrm{C}$ in a humidified $5 \% \mathrm{CO}_{2}$ incubator. For cAMP assays, the cells were transfected using the FuGENE 6 (Roche) transfection reagent 
Table 1 Primers, probes and RT-PCR conditions.

\begin{tabular}{|c|c|c|c|c|}
\hline Primer and probes & $\begin{array}{l}\text { Primer sequences from } \\
5^{\prime} \text {-end to } 3^{\prime} \text {-end }\end{array}$ & $\begin{array}{l}\text { Annealing temperature } \\
\text { in }{ }^{\circ} \mathbf{C}\end{array}$ & $\begin{array}{l}\text { Elongation time } \\
\text { in } \mathbf{s}\end{array}$ & $\begin{array}{c}\mathrm{MgCl}_{2} \text { concentration } \\
\text { in } \mathrm{mM}\end{array}$ \\
\hline $\begin{array}{l}\text { RGS2-f1 } \\
\text { RGS2-r1 } \\
\text { RGS2X } \\
\text { RGS2LC }\end{array}$ & $\begin{array}{l}\text { actatgtgcaagggtatt } \\
\text { aagacagattttggcactc } \\
\text { tttcacacatcatttttaacaatgcaaac- } X \\
\text { LCRED640-cggaccatttcagttttagcattacat-P }\end{array}$ & 49 & 8 & 5 \\
\hline $\begin{array}{l}\text { RGS6-f1 } \\
\text { RGS6-r1 } \\
\text { RGS6X } \\
\text { RGS6LC }\end{array}$ & $\begin{array}{l}\text { gtgcccatcagaacagtcaagagc } \\
\text { tacggagcctggaacgataaaag } \\
\text { ggtactgacattgtgcagtggcttatgaaga-X } \\
\text { LCRED640-cctttccattgaggacccagttgaagca-P }\end{array}$ & 55 & 9 & 5 \\
\hline $\begin{array}{l}\text { RGS9-f1 } \\
\text { RGS9-r1 } \\
\text { RGS9X } \\
\text { RGS9LC }\end{array}$ & $\begin{array}{l}\text { tctagccccttctcctcctcctg } \\
\text { gaccagctgcactcccctttct } \\
\text { cagatggttggtcgccggatgaagc- } X \\
\text { LCRED640-ctgggtgaggcgaaaggcttcctg-P }\end{array}$ & 60 & 9 & 5 \\
\hline $\begin{array}{l}\text { RGS10-f1 } \\
\text { RGS10-r1 } \\
\text { RGS10X } \\
\text { RGS10LC }\end{array}$ & $\begin{array}{l}\text { ttttaaaacacaagcgaacc } \\
\text { aaataacaaagcaatgataaacc } \\
\text { tggaagctcttttagctgcagtttga-X } \\
\text { LCRED640-tcaggcaaatcttcttcctcttcctc-P }\end{array}$ & 47 & 8 & 3 \\
\hline $\begin{array}{l}\text { RGS12-f1 } \\
\text { RGS12-r1 } \\
\text { RGS12X } \\
\text { RGS12LC }\end{array}$ & $\begin{array}{l}\text { atttgggcggggaactggactcac } \\
\text { cattgctgctcaggctgttgttgc } \\
\text { actcgctcccttgatgatcttgagtctgc-X } \\
\text { LCRED640-ctgtgtctgatggcgagttgacggg-P }\end{array}$ & 61 & 9 & 3 \\
\hline $\begin{array}{l}\text { RGS16-f1 } \\
\text { RGS16-r1 } \\
\text { RGS16X } \\
\text { RGS16LC }\end{array}$ & $\begin{array}{l}\text { taatttcagtttgcctctac } \\
\text { aaccagctccatttgtca } \\
\text { cctctgaatgtgctgggaacctc-X } \\
\text { LCRED640-tggagcctgtcaggaactcctca-P }\end{array}$ & 50 & 8 & 5 \\
\hline $\begin{array}{l}\beta \text {-actin-f } \\
\beta \text {-actin-r } \\
\beta \text {-actinX } \\
\beta \text {-actinLC }\end{array}$ & $\begin{array}{l}\text { ggcctcgctgtccaccttcc } \\
\text { tgtcaccttcaccgttccagtttt } \\
\text { gcctagaagcatttgcggtggacgatg-X } \\
\text { LCRED640-aggggccggactcgtcatactcctgct-P }\end{array}$ & 55 & 9 & 4 \\
\hline
\end{tabular}

$\mathrm{X}=$ flourescein label; LCRED604 = LightCyclerRed 640; $\mathrm{P}=$ phosphorylation.

according to the manufacturer's instructions. In brief, $2 \times 10^{5}$ COS-7 cells/well were seeded into 12-well plates $24 \mathrm{~h}$ before cotransfection with $1 \mu \mathrm{g} /$ well plasmid constructs $(0.5 \mu \mathrm{g}$ TSHR, $0.5 \mu \mathrm{g}$ RGS protein or supplemented with empty pcDNA 3.1 vector to, finally, $1 \mu \mathrm{g}$ transfected DNA) containing the coding sequence of the TSHR and RGS protein 2. The coding sequence of RGS 2 was amplified by RT-PCR from human thyroid cDNA (primer; Table 1) and subcloned in pcDNA 3.1 vector. Both strands of the RGS cDNA clones were checked by sequencing. Functional assays were performed $48 \mathrm{~h}$ after transfection and repeated twice.

\section{Measurement of cAMP}

For cAMP assays, COS-7 cells were washed once in serum-free DMEM, followed by a preincubation with the same medium containing $1 \mathrm{mM}$ 3-isobutyl-1methyl-xanthine (Sigma Chemical Co., St Louis, MO, USA) for $20 \mathrm{~min}$ at $37^{\circ} \mathrm{C}$ in a humidified $5 \% \mathrm{CO}_{2}$ incubator. Subsequently, cells were stimulated with bovine TSH $(100 \mathrm{mU} / \mathrm{ml})$ for $1 \mathrm{~h}$ to obtain maximal response. Reactions were terminated by aspiration of the medium and addition of $0.5 \mathrm{ml} 0.1 \mathrm{M} \mathrm{HCl}$. Supernatants were collected and dried. The cAMP content of the cell extracts was determined with a commercial kit (Amersham
Pharmacia Biotech, Braunschweig, Germany) according to the manufacturer's instructions.

\section{Stimulation of inositolphosphate (IP) formation}

Inositolphosphates were measured as described (34). Forty hours after transfection, $2 \times 10^{5}$ COS-7 cells were incubated with $2 \mu \mathrm{Ci} / \mathrm{ml}\left[\right.$ myo- $\left.^{3} \mathrm{H}\right]$ inositol (18.6 Ci/mmol; Amersham Pharmacia Biotech) for $8 \mathrm{~h}$. Thereafter, cells were preincubated in serum-free DMEM containing $10 \mathrm{mM} \mathrm{LiCl}$ for $20 \mathrm{~min}$. Subsequently, cells were stimulated with bovine TSH for $1 \mathrm{~h}$ as described previously. Stimulation was terminated by aspiration of the medium and addition of $0.5 \mathrm{ml} \mathrm{3 \%}$ perchloric acid. TSH-induced increases in intracellular inositolphosphate levels were determined by anion exchange chromatography. IP values are expressed as the percentage of radioactivity incorporated in inositolphosphates and phosphatidylinositoles.

\section{Fluorescence-activated cell sorter (FACS) analysis}

For determination of the TSHR cell surface expression, transfected cells were incubated with anti-human TSHR antibody (2C11; Serotec Ltd, Oxford, Oxon, UK; 
$10 \mu \mathrm{g} / \mathrm{ml}$ in PBS containing $0.1 \%$ bovine serum albumin (BSA)). After two washes with PBS $(0.1 \%$ BSA) cells were incubated with the fluorescent conjugated $\mathrm{F}\left(\mathrm{ab}^{\prime}\right) 2$ rabbit anti-mouse IgG secondary antibody (Star9B; Serotec Ltd; 1:100 dilution in PBS containing $0.1 \%$ BSA) for $1 \mathrm{~h}$ on ice in the dark. The fluorescence of 10000 cells per tube was assayed by a FACScan Cytofluorometer (Becton Dickinson, San Jose, CA, USA).

\section{Data analysis}

RGS mRNA results are expressed as means \pm s.E.M. of three independent experiments carried out in duplicate. ANOVA was used to evaluate the differences between all groups. Differences between stimulated and unstimulated cells within significant groups were evaluated using Dunnett's post hoc test.

Data of the cAMP accumulation in COS-7 are given as means \pm S.E. of one representative experiment (out of four), carried out in duplicate. Statistical analysis was carried out by Student's $t$-test. Data of the IP accumulation in COS-7 cells are given as means \pm s.E. of one representative experiment (out of four), carried out in duplicate. Statistical analysis was carried out by Student's t-test. Data of the FACS analysis are given as means \pm S.E.M. of four experiments, carried out in duplicate. Statistical analysis was carried out by Student's $t$ test.

\section{Results}

\section{TSH regulates RGS 2 mRNA expression}

RGS mRNA expression is cell type specific and highly regulated by several extra- and intracellular stimuli. To analyze the TSH dependence of RGS mRNA expression we checked the RGS mRNA levels in three human primary thyroid cell cultures after stimulation with $1 \mathrm{mU} / \mathrm{ml}$ TSH (Fig. 1). The expression of RGS 2 mRNA was significantly up-regulated within $1 \mathrm{~h}$ $(P<0.05)$ after TSH stimulation and reached a maximum of approximately 20-fold over unstimulated cells after $4 \mathrm{~h}(P<0.01$; Fig. 1a). In contrast, the mRNA expression levels of the other RGS proteins were not significantly changed compared with cells not treated with
TSH $(P>0.05$; Fig. $1 b-f)$. To prove the quality of our primary thyroid cell culture system and the specificity of the TSH we checked the expression of the thyroid peroxidase (TPO) mRNA expression. The TPO mRNA expression increased up to 20 -fold within $24 \mathrm{~h}$ after TSH stimulation $(P<0.01$; Fig. $1 \mathrm{~g})$.

\section{RGS protein expression reduces TSHR signaling}

RGS proteins deliver GAP activity towards $\mathrm{G} \alpha$ proteins and force the reassociation of $G$ protein $\alpha$ and $\beta \gamma$ subunits, thereby blunting the $G$ protein signaling of $\mathrm{G}$ protein-coupled receptors. To investigate if the TSHregulated RGS 2 protein is able to desensitize the TSHR we co-expressed RGS 2 together with the TSHR in COS-7 cells. Overexpression of RGS 2 mRNA was checked by RT-PCR. Transfection efficiency and TSHR cell surface expression were checked by FACS analysis as described previously (34). The cell surface expression of the TSHR cotransfected with RGS 2 was $96 \pm 7 \%$ $(P=0.17)$ in comparison with the TSHR, which was cotransfected with an empty pSVL-vector. Overexpression of RGS 2 did not significantly influence the TSHstimulated cAMP accumulation in COS-7 cells (Fig. 2a). In contrast to this result for the TSHR cAMP pathway, overexpression of RGS 2 protein blunted the IP content of the TSH-stimulated TSHR by decreasing the TSH-stimulated IP production of the TSHR to $62 \%(P<0.05)$ of the stimulated TSHR coexpressed with the expression vector alone (Fig. 2b).

\section{Discussion}

Cell-specific expression of a broad range of RGS mRNAs has been shown in different tissues: six out of 16 RGS mRNAs have been found in human smooth muscle cells (30), the expression and distinct regulation of RGS 1, RGS 2 and RGS 16 mRNA has been described in human lymphocytes $(14,35,36)$, and a cell type-specific pattern of expression and regulation of ten RGS proteins (RGS 2-RGS 11) was also detected in rat brain $(21,37)$. In addition, in rat cardiac myocytes, mRNAs of ten different RGS proteins have been found (38). Since we have recently shown the expression of nine RGS mRNAs in

Figure $1 \mathrm{TSH}$-stimulated RGS mRNA expression in primary cultures of thyroid epithelial cells. RGS mRNA expression was stimulated with $1 \mathrm{mU} / \mathrm{ml}$ bovine TSH in primary cultures of thyroid epithelial cells and determined after 1, 2, 4, 8, 12, 24 and $48 \mathrm{~h}$. The real-time RT-PCR was performed using a LightCycler. Each point was normalized to $\beta$-actin and is expressed as fold of unstimulated cells. The results are expressed as the means \pm S.E.M. of three independent experiments. ANOVA was used to evaluate the differences between all groups. Differences between stimulated and unstimulated cells within significant groups were evaluated using Dunnett's test $\left({ }^{*} P<0.05,{ }^{* *} P<0.01\right)$. (a) Significant up-regulation of RGS 2 mRNA after TSH stimulation in comparison with unstimulated cells $(P<0.001)$. (b) No significant differences of RGS 6 mRNA expression after TSH stimulation in comparison with unstimulated cells $(P>0.05)$. (c) No significant differences of RGS 9 mRNA expression after TSH stimulation in comparison with unstimulated cells $(P>0.05)$. (d) No significant differences of RGS 10 mRNA expression after TSH stimulation in comparison with unstimulated cells $(P>0.05)$. (e) No significant differences of RGS 12 mRNA expression after TSH stimulation in comparison with unstimulated cells $(P>0.05)$. (f) No significant differences of RGS 16 mRNA expression after TSH stimulation in comparison with unstimulated cells $(P>0.05)$. (g) To prove the quality of the primary thyroid cell culture system and the specificity of the TSH results we checked the up-regulation of the TPO mRNA $(P<0.001)$. 
human thyroid tissue with a differential expression of six out of these nine RGS mRNAs between hot and cold thyroid nodules and their corresponding normal surrounding tissue (A Tönjes, S Miedlich, H-P Holzapfel, M Eszlinger \& R Paschke, unpublished observations), we subsequently investigated the regulation of RGS gene expression after TSHR stimulation of the six in

a)

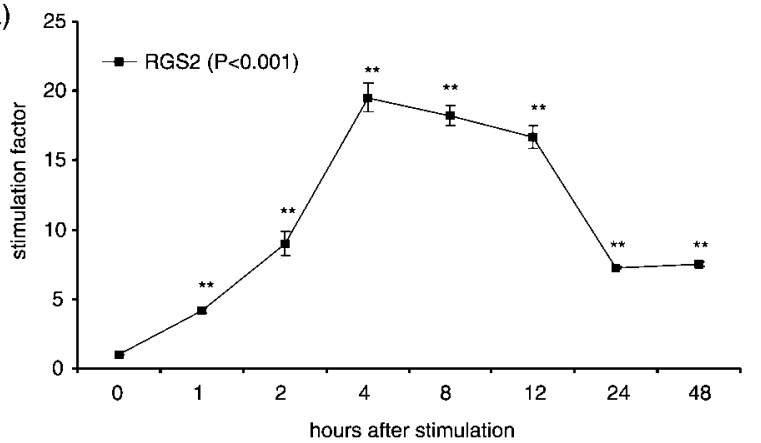

c)
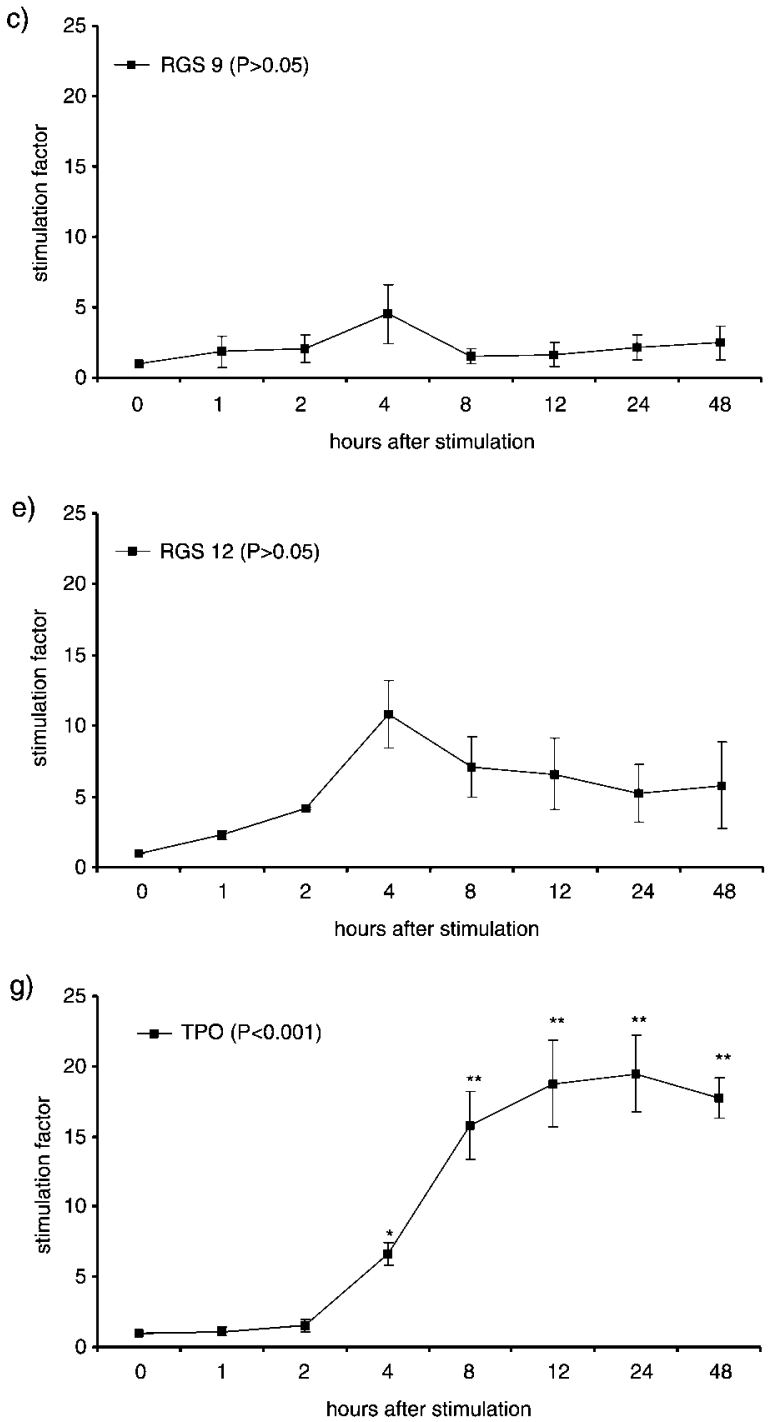

thyroid nodules differentially expressed RGS mRNAs. Interestingly, only RGS 2 was found to be significantly up-regulated after stimulation with TSH (Fig. 1a).

RGS 2 mRNA expression has been shown in many cell types and is highly regulated (39). In PC 12 cells, mRNA expression of RGS 2 was up-regulated by cAMP (40). RGS 2 mRNA expression has also been

b)

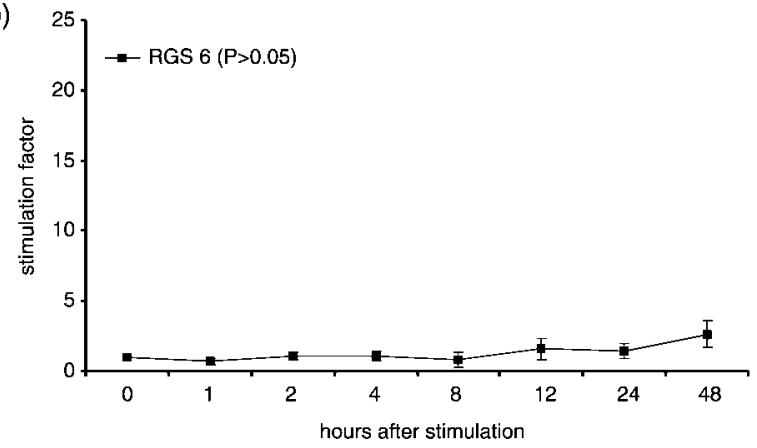

d)
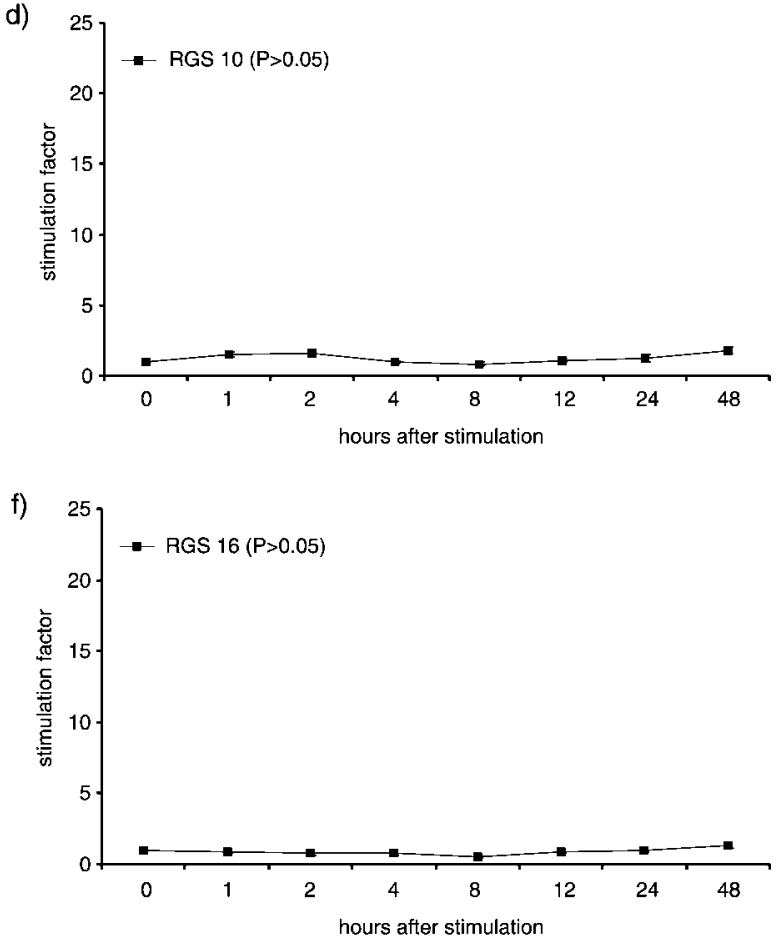


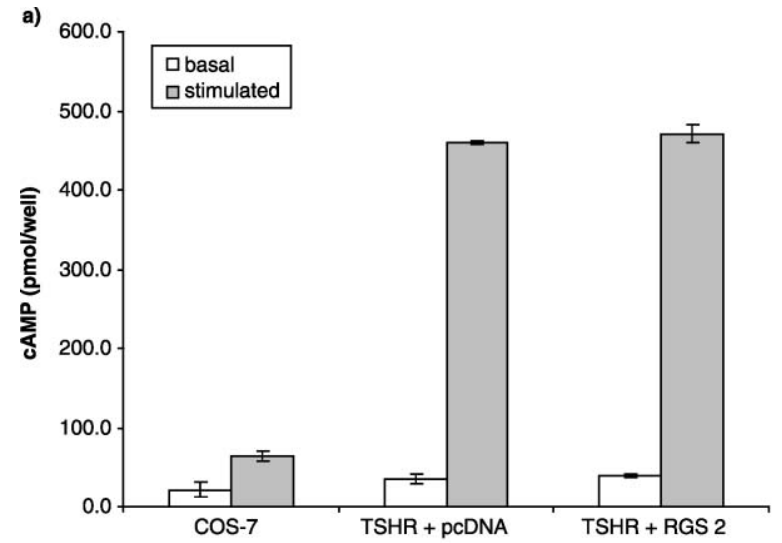

b)

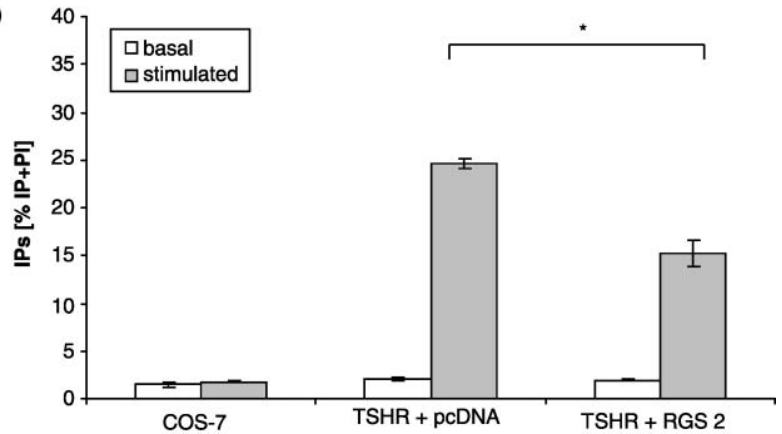

Figure 2 (a) RGS 2 expression does not influence TSHR cAMP signaling in COS-7 cells. cAMP accumulation in COS-7 cells after co-expression of the TSHR with RGS 2 or pcDNA3.1 vector and stimulation with $100 \mathrm{mU} / \mathrm{ml}$ bovine TSH for $1 \mathrm{~h}$. Data are given as means $\pm S$.E. of one representative experiment, carried out in duplicate. (b) RGS 2 overexpression suppresses TSHR IP3 signaling in COS-7 cells. IP3 accumulation in COS-7 cells after co-expression of the TSHR with RGS 2 or pcDNA 3.1 vector and stimulation with $100 \mathrm{mU} / \mathrm{ml}$ TSH for $1 \mathrm{~h}$. Data are given as means \pm S.E. of one representative experiment, carried out in duplicate $\left({ }^{\star} P<0.05\right)$

shown to be rapidly increased by different drugs and a single seizure in the hippocampus (37), by PTH treatment and direct cAMP stimulation in bone cells (9), by stimulation of protein kinase $\mathrm{C}$ via activation of muscarinic receptors (41) and by forskolin stimulation of PC 12 cells (40). In primary cultures of thyroid epithelial cells, TSH stimulation also resulted in a very rapid and dramatic increase of RGS 2 mRNA expression (Fig. 1a), indicating the biological relevance of this regulatory protein in thyroid epithelial cells.

The main signaling cascades of the TSHR are the cAMP pathway including $G_{\mathrm{s}} \alpha$ and protein kinase $A$ and signal transduction via IP3 and PLC. By coexpression of RGS 2 and the TSHR in COS-7 cells (Fig. 2), we demonstrated the inhibition of the stimulated $\mathrm{G}_{\mathrm{q}} \alpha$ pathway of the TSHR while the stimulated $\mathrm{G}_{\mathrm{s}} \alpha$ signal transduction cascade was not influenced by RGS 2 overexpression. Our results are in agreement with previous data showing that RGS 2 blocks $\mathrm{G}_{\mathrm{q}} \alpha$ mediated signaling due to its potent $\mathrm{G}_{\mathrm{q}} \alpha$ GAP activity
(39). This RGS 2 inhibition of TSHR-mediated IP3 signaling is likely to be due to the termination of the $\mathrm{G}_{\mathrm{q}} \alpha$ activation of PLC $\beta$, as has previously been shown in vitro (35). However, RGS proteins cannot account for classical homologous TSHR desensitization because an up-regulation of RGS 2 mRNA has been shown in other cell systems by cAMP, indicating a heterologous effect (39). In addition, RGS 2 may, independent of its GAP activity, increase the availability

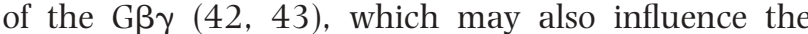

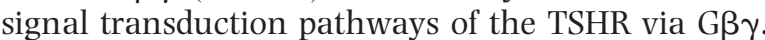

Like all known RGS proteins, with the exception of RGS-PX1 (27), RGS 2 lacks $\mathrm{G}_{\mathrm{s}} \alpha$ GAP activity. However, RGS 2 inhibits $G_{s} \alpha$ signaling by direct inhibition of several adenylyl cyclases (44). The in vitro effect of overexpressed RGS 2 on $\mathrm{G}_{\mathrm{s}} \alpha$ strongly depends on the cellular expression of specific signal transduction components such as adenylyl cyclases (44). In thyroid cells, adenylyl cyclases III and V may serve as targets for RGS 2 action (45). The COS-7 cell line used in our experiments is likely to express subtypes of adenylyl cyclases other than thyroid epithelial cells (45). This could be the underlying reason for the uninhibited cAMP response in our cotransfection experiments.

In contrast to the strong TSH-induced acute increase of RGS 2 mRNA expression in our primary thyroid cell culture (Fig. 1a) we found a decreased expression of RGS 2 mRNA in hot thyroid nodules (A Tönjes, S Miedlich, H-P Holzpafl, M Eszlinger \& R Paschke, unpublished observations). These different results can most likely be explained by defects in the RGS regulation pathway or by additional counter-regulatory pathways which occur in the chronically proliferating hot thyroid nodules. The increased expression of $\beta$-arrestin 2 in hot thyroid nodules (46) is possibly an example of such an additional counter-regulation. $\beta$-arrestin 2 desensitizes the TSHR followed by a blocked $\mathrm{G}$ protein coupling. This could lead to a decreased $\mathrm{G}_{\mathrm{q}}$ stimulation, subsequently followed by a reduction of RGS 2 mRNA expression. However, further investigations are necessary to clarify these regulatory mechanisms and to explore the possible involvement of RGS proteins in the pathophysiology of thyroid diseases.

In conclusion, TSH-dependent RGS 2 mRNA expression and the suppression of $\mathrm{TSH}-\mathrm{G}_{\mathrm{q}} \alpha$ signaling by overexpression of RGS 2 imply that RGS 2 is involved in TSHR-induced $\mathrm{G}_{\mathrm{q}}$ signal transduction.

\section{Acknowledgements}

This work was supported by a grant from the Deutsche Forschungsgemeinsschaft (DFG Ho1764/4-1) and the Bundesministerium für Bildung und Forschung (BMBF) Interdisciplinary Centre for Clinical Research at the University of Leipzig (01 KS 9504, project B14). 


\section{References}

1 Koelle MR \& Horvitz HR. EGL-10 regulates G protein signaling in the $C$. elegans nervous system and shares a conserved domain with many mammalian proteins. Cell 199684 115-125.

2 Watson N, Linder ME, Druey KM, Kehrl JH \& Blumer KJ. RGS family members: GTPase-activating proteins for heterotrimeric G-protein alpha-subunits. Nature 1996383 172-175.

3 Druey KM, Blumer KJ, Kang VH \& Kehrl JH. Inhibition of G-protein-mediated MAP kinase activation by a new mammalian gene family. Nature $1996379742-746$.

4 Zheng B, De Vries L \& Gist FM. Divergence of RGS proteins: evidence for the existence of six mammalian RGS subfamilies. Trends in Biochemical Sciences 199924 411-414.

5 Garrison TR, Zhang Y, Pausch M, Apanovitch D, Aebersold R \& Dohlman HG. Feedback phosphorylation of an RGS protein by MAP kinase in yeast. Journal of Biological Chemistry $1999 \mathbf{2 7 4}$ 36387-36391.

6 Dohlman HG, Song J, Ma D, Courchesne WE \& Thorner J. Sst2, a negative regulator of pheromone signaling in the yeast Saccharomyces cerevisiae: expression, localization, and genetic interaction and physical association with Gpal (the G-protein alpha subunit). Molecular and Cellular Biology $1996 \quad 16$ 5194-5209.

7 Saitoh O, Kubo Y, Miyatani Y, Asano T \& Nakata H. RGS8 accelerates G-protein-mediated modulation of $\mathrm{K}+$ currents. Nature $1997390525-529$.

8 Kim E, Arnould T, Sellin L, Benzing T, Comella N, Kocher O, Tsiokas L, Sukhatme VP \& Walz G. Interaction between RGS7 and polycystin. PNAS 199996 6371-6376.

9 Miles RR, Sluka JP, Santerre RF, Hale LV, Bloem L, Boguslawski G, Thirunavukkarasu K, Hock JM \& Onyia JE. Dynamic regulation of RGS2 in bone: potential new insights into parathyroid hormone signaling mechanisms. Endocrinology 2000141 28-36.

10 Yan Y, Chi PP \& Bourne HR. RGS4 inhibits Gq-mediated activation of mitogen-activated protein kinase and phosphoinositide synthesis. Journal of Biological Chemistry $1997 \mathbf{2 7 2}$ $11924-11927$.

11 Zhang S, Watson N, Zahner J, Rottman JN, Blumer KJ \& Muslin AJ. RGS3 and RGS4 are GTPase activating proteins in the heart. Journal of Molecular and Cellular Cardiology 1998 30 269-276.

12 Panetta R, Guo Y, Magder S \& Greenwood MT. Regulators of G-protein signaling (RGS) 1 and 16 are induced in response to bacterial lipopolysaccharide and stimulate c-fos promoter expression. Biochemical and Biophysical Research Communications 1999259 550-556.

13 Zhong $\mathrm{H}$ \& Neubig RR. Regulator of $G$ protein signaling proteins: novel multifunctional drug targets. Journal of Pharmacology and Experimental Therapeutics $2001297837-845$.

14 Beadling C, Druey KM, Richter G, Kehrl JH \& Smith KA. Regulators of $\mathrm{G}$ protein signaling exhibit distinct patterns of gene expression and target $\mathrm{G}$ protein specificity in human lymphocytes. Journal of Immunology 1999162 2677-2682.

15 Chen CK, Wieland T \& Simon MI. RGS-r, a retinal specific RGS protein, binds an intermediate conformation of transducin and enhances recycling. PNAS $19969312885-12889$.

16 Cowan CW, Fariss RN, Sokal I, Palczewski K \& Wensel TG. High expression levels in cones of RGS9, the predominant GTPase accelerating protein of rods. PNAS 199895 5351-5356.

17 Granneman JG, Zhai Y, Zhu Z, Bannon MJ, Burchett SA, Schmidt CJ, Andrade R \& Cooper J. Molecular characterization of human and rat RGS 9L, a novel splice variant enriched in dopamine target regions, and chromosomal localization of the RGS 9 gene. Molecular Pharmacology 199854 687-694.

18 Reif K \& Cyster JG. RGS molecule expression in murine B lymphocytes and ability to down-regulate chemotaxis to lymphoid chemokines. Journal of Immunology 2000164 4720-4729.

19 Snow BE, Antonio L, Suggs S, Gutstein HB \& Siderovski DP. Molecular cloning and expression analysis of rat Rgs12 and Rgs14.
Biochemical and Biophysical Research Communications 1997233 $770-777$.

20 Thomas EA, Danielson PE \& Sutcliffe JG. RGS9: a regulator of G-protein signalling with specific expression in rat and mouse striatum. Journal of Neuroscience Research $1998 \mathbf{5 2}$ $118-124$.

21 Gold SJ, Ni YG, Dohlman HG \& Nestler EJ. Regulators of G-protein signaling (RGS) proteins: region-specific expression of nine subtypes in rat brain. Journal of Neuroscience $1997 \quad \mathbf{1 7}$ $8024-8037$

22 Dohlman HG \& Thorner J. RGS proteins and signaling by heterotrimeric G proteins. Journal of Biological Chemistry 1997272 $3871-3874$

23 Siderovski DP, Strockbine B \& Behe CI. Whither goest the RGS proteins? Critical Reviews in Biochemistry and Molecular Biology 1999 $34215-251$.

24 Hajdu-Cronin YM, Chen WJ, Patikoglou G, Koelle MR \& Sternberg PW. Antagonism between G(o)alpha and G(q)alpha in Caenorhabditis elegans: the RGS protein EAT-16 is necessary for $\mathrm{G}(\mathrm{o})$ alpha signaling and regulates G(q)alpha activity. Genes and Development 199913 1780-1793.

25 Natochin M, Granovsky AE \& Artemyev NO. Regulation of transducin GTPase activity by human retinal RGS. Journal of Biological Chemistry 1997272 17444-17449.

26 Wieland T, Bahtijari N, Zhou XB, Kleuss C \& Simon MI. Polarity exchange at the interface of regulators of $\mathrm{G}$ protein signaling with $\mathrm{G}$ protein alpha-subunits. Journal of Biological Chemistry $200027528500-28506$.

27 Zheng B, Ma YC, Ostrom RS, Lavoie C, Gill GN, Insel PA, Huang XY \& Farquhar MG. RGS-PX1, a GAP for GalphaS and sorting nexin in vesicular trafficking. Science 2001294 1939-1942.

28 Laugwitz KL, Allgeier A, Offermanns S, Spicher K, Van Sande J, Dumont JE \& Schultz G. The human thyrotropin receptor: a heptahelical receptor capable of stimulating members of all four $G$ protein families. PNAS 199693 116-120.

29 Allgeier A, Laugwitz KL, Van Sande J. Schultz G \& Dumont JE. Multiple G-protein coupling of the dog thyrotropin receptor. Molecular and Cellular Endocrinology 1997 127 81-90.

30 Grant SL, Lassegue B, Griendling KK, Ushio-Fukai M, Lyons PR \& Alexander RW. Specific regulation of RGS2 messenger RNA by angiotensin II in cultured vascular smooth muscle cells. Molecular Pharmacology 200057 460-467.

31 Denecke B, Meyerdierks A \& Bottger EC. RGS1 is expressed in monocytes and acts as a GTPase-activating protein for G-protein-coupled chemoattractant receptors. Journal of Biological Chemistry 1999274 26860-26868.

32 Chen CK, Burns ME, He W, Wensel TG, Baylor DA \& Simon MI. Slowed recovery of rod photoresponse in mice lacking the GTPase accelerating protein RGS9-1. Nature $2000 \mathbf{4 0 3}$ $557-560$.

33 Eszlinger M, Krohn K \& Paschke R. Complementary DNA expression array analysis suggests a lower expression of signal transduction proteins and receptors in cold and hot thyroid nodules. Journal of Clinical Endocrinology and Metabolism 2001 $864834-4842$.

34 Holzapfel HP, Bergner B, Wonerow P \& Paschke R. Expression of $\mathrm{G}(\mathrm{alpha})(\mathrm{s})$ proteins and TSH receptor signalling in hyperfunctioning thyroid nodules with TSH receptor mutations. European Journal of Endocrinology 2002147 109-116.

35 Heximer SP, Cristillo AD \& Forsdyke DR. Comparison of mRNA expression of two regulators of G-protein signaling, RGS1/BL34/1R20 and RGS2/G0S8, in cultured human blood mononuclear cells. DNA and Cell Biology $1997 \quad 16$ 589-598.

36 Moratz C, Kang VH, Druey KM, Shi CS, Scheschonka A, Murphy PM, Kozasa T \& Kehrl JH. Regulator of G protein signaling 1 (RGS1) markedly impairs Gi alpha signaling responses of B lymphocytes. Journal of Immunology $2000 \mathbf{1 6 4}$ $1829-1838$. 
37 Ingi T, Krumins AM, Chidiac P, Brothers GM, Chung S, Snow BE, Barnes CA, Lanahan AA, Siderovski DP, Ross EM, Gilman AG \& Worley PF. Dynamic regulation of RGS2 suggests a novel mechanism in G-protein signaling and neuronal plasticity. Journal of Neuroscience $1998187178-7188$.

38 Kardestuncer T, Wu H, Lim AL \& Neer EJ. Cardiac myocytes express mRNA for ten RGS proteins: changes in RGS mRNA expression in ventricular myocytes and cultured atria. FEBS Letters $1998438285-288$.

39 Kehrl JH \& Sinnarajah S. RGS2: a multifunctional regulator of G-protein signaling. International Journal of Biochemistry and Cell Biology $200234432-438$.

40 Pepperl DJ, Shah-Basu S, VanLeeuwen D, Granneman JG \& MacKenzie RG. Regulation of RGS mRNAs by cAMP in PC12 cells. Biochemical and Biophysical Research Communications 1998 $24352-55$.

41 Song L, De Sarno P \& Jope RS. Muscarinic receptor stimulation increases regulators of G-protein signaling 2 mRNA levels through a protein kinase C-dependent mechanism. Journal of Biological Chemistry $199927429689-29693$.
42 Doupnik CA, Davidson N, Lester HA \& Kofuji P. RGS proteins reconstitute the rapid gating kinetics of gbetagamma-activated inwardly rectifying K + channels. PNAS 199794 10461-10466.

43 Bunemann M \& Hosey MM. G-protein coupled receptor kinases as modulators of G-protein signalling. Journal of Physiology 1999 $5175-23$.

44 Sinnarajah S, Dessauer CW, Srikumar D, Chen J, Yuen J, Yilma S, Dennis JC, Morrison EE, Vodyanoy V \& Kehrl JH. RGS2 regulates signal transduction in olfactory neurons by attenuating activation of adenylyl cyclase III. Nature 2001409 1051-1055.

45 Vanvooren V, Allgeier A, Cosson E, Van Sande J, Defer N, Pirlot M, Hanoune J \& Dumont JE. Expression of multiple adenylyl cyclase isoforms in human and dog thyroid. Molecular and Cellular Endocrinology $2000 \mathbf{1 7 0} 185-196$.

46 Voigt C, Holzapfel H \& Paschke R. Expression of beta-arrestins in toxic and cold thyroid nodules. FEBS Letters $2000 \mathbf{4 8 6}$ 208-212.

Received 8 April 2004

Accepted 9 June 2004 